ISSN 0258-7122

Bangladesh J. Agril. Res. 38(4): 573-578, December 2013

\title{
EFFECT OF SEED STALK PRUNING AND BORON APPLICATION ON THE SEED YIELD OF SUMMER ONION (Allium cepa L.) IN THE HIGH BARIND TRACT
}

\author{
M. M. R. SARKER ${ }^{1}$, M. J. U. SARKER ${ }^{2}$, A. S. M. M. R. KHAN ${ }^{3}$ \\ M. S. ISLAM ${ }^{4}$ AND M. S. HOSSAIN ${ }^{5}$
}

\begin{abstract}
The experiment was carried out at FSRD site, Kadamshahar, Godagari, Rajshahi during 2009-10 and 2010-11 to find out the number of seed stalk and optimum boron dose for seed production of summer onion in High Barind Tract (AEZ 26). The treatments comprised three levels of seed stalk (0, 4, and 6) and three rates of boron application $(0,1$, and $2 \mathrm{~kg} / \mathrm{ha})$. It revealed that the seed stalks and boron either in single or combination had significant effect on the yield and yield contributing characters of onion seed. The combination comprising 4 stalks with $2 \mathrm{~kg} \mathrm{~B} / \mathrm{ha}$ and 6 stalks with $1 \mathrm{~kg} \mathrm{~B} / \mathrm{ha}$ were found to be the best choice for achieving higher seed yield of onion. The highest seeded fruit/umbel (4.06 and 4.55) and seed yield (669 and $713 \mathrm{~kg} / \mathrm{ha}$ ) were recorded from 6 stalks/plant fertilized with $1 \mathrm{~kg}$ boron/ha which was statistically identical to 6 stalks/plant fertilized with $2 \mathrm{~kg}$ boron/ha and 4 stalks/plant with $2 \mathrm{~kg} / \mathrm{ha}$ boron in the High Barind Tract.
\end{abstract}

Keywords: Seed stalk pruning, boron application, summer onion, high Barind tract.

\section{Introduction}

Onion (Allium cepa L.) is one of the most important spice crops in Bangladesh. Among the spice crops, it ranks first with an annual production of 589 thousand metric tons which is very low compared to the estimated annual requirement of about 836 thousand metric tons (Krishi Dairy, 2007). Seed has a unique role to increase onion production. Onion is an important spice crop in Bangladesh. It ranks first in production (889000 MT) and second in area (125101 ha) among the spices (BBS, 2008). It covers almost $36 \%$ of the total areas under spices. The mean yield of onion in Bangladesh is very low (4 t/ha) compared to world average of $17.27 \mathrm{t} / \mathrm{ha}$ (FAO, 1998). Annually Bangladesh produced only 150 metric tons of onion seed as against the requirement of 300 metric tons (Rahim et al., 1993). Therefore, a great scarcity of onion seed is noticed every year. Improved seed contributes substantially to enhance crop yield as high as $30 \%$ (Shaikh et al., 2007) On the other hand, Barind Tract is a potential area for

\footnotetext{
${ }^{1}$ Senior Scientific Officer, ${ }^{2}$ Chief Scientific Officer, ${ }^{3}$ Principal Scientific Officer, OnFarm Research Division, Bangladesh Agricultural Research Institute (BARI), Gazipur, ${ }^{4}$ Principal Scientific Officer, On-Farm Research Division, BARI, Pabna, ${ }^{5}$ Senior Scientific Officer, On-Farm Research Division, BARI, Barind, Rajshahi, Bangladesh.
} 
quality seed production of its inherent environmental condition, usually less humid condition prevails throughout the whole rabi season and so comparatively less pest infestation is observed during that time. That is why, onion seed production in High Barind Tract is increasing day by day. Different studies revealed that boron application and number of seed stalks are two important key factors for quality seed production. Brewster (1994) observed various differences in average seed yield as it depends on genotype, locality, season, and method of seed production. According to Thompson (1979), high quality seed is critical input on which all other inputs will depend for their full effectiveness. In onion, several studies revealed that number of seed stalks is important factor for the seed yield and quality. On the other hand, boron is essential for seed setting and formation as well as seed vigour and viability in onion and so, its deficiency may be the reason of floral sterility. Therefore, considering prerequisite, the present study was undertaken to find out the keeping number of seed stalks and optimum boron dose for seed production of summer onion in High Barind Tract.

\section{Materials and Method}

The experiment was conducted at Farming System Research and Development (FSRD) site, Kadamshahar, Godagari, Rajshahi for two consecutive years (200910 and 2010-11). The soil of the experimental plots belongs to Amnura series under AEZ 26. Before starting the experiment, composite soil sample $(0-15 \mathrm{~cm})$ was collected and analyzed in the laboratory. The soil had following characteristics, such as $\mathrm{pH} 5.5$, OM $0.98 \%$, basal $\mathrm{N} 0.06 \%$, available $\mathrm{P} 9.36$ $\mathrm{mg} / \mathrm{g}, \mathrm{K} 0.26 \mathrm{meq} / 100 \mathrm{~g}$ soil, S $14.51 \mathrm{mg} / \mathrm{g}, \mathrm{Zn} 1.05 \mathrm{mg} / \mathrm{g}$, and B $0.19 \mathrm{mg} / \mathrm{g}$. The treatments comprised three levels of seed stalk $(0,4$, and 6$)$ with three doses of boron application ( 0,1 , and $2 \mathrm{~kg} / \mathrm{ha})$. The experiment was laid out in a factorial randomized complete block design with three replications. Onion variety BARI Piaz-5 was used in the study. The unit plot size was $2 \mathrm{~m} \times 3 \mathrm{~m}$. The bulbs were transplanted at the spacing of $25 \mathrm{~cm} \mathrm{x} 20 \mathrm{~cm}$ during $1^{\text {st }}$ week of November 2009 and 2010. The soil of experimental plot was treated by Furadan 5G @ 7.5 kg/ha before transplanting the bulbs. Rovral (@2 g/L water) and Bavistin (1 g/L water) were used simultaneously at 8-10 days intervals during vegetative stage. The plot was irrigated 7 times at 7-10 day intervals before seed maturity. Other operations viz., mulching and weeding were done in order to support normal plant growth. The crop was harvested at maturity during 10 to 15 April 2010 and 2011. Observations were made on yield components from 10 randomly selected plants per plot. Yield data was taken as plot-wise and thereafter converted into kg/ha. The data were analyzed statistically and the mean differences were adjudged by Duncan’s Multiple Range Test (Gomez and Gomez, 1984). 


\section{Effect of seed stalk}

Both the years, significant variation was observed in seed yield and yield attributes of onion with the variation of number of seed stalks (Table 1). In 20092010, the maximum number of seeded fruits/umbel (303.24) and seed weight/umbel (3.95 g) were noted from keeping 4 stalks/plant. But in 2010-2011, maximum number of seeded fruits/umbel (297.0) and seed weight/umbel (3.85 g) were noted from keeping 6 stalks/plant. Both the years, maximum number of seeds/umbel (690 and 703.7) and 1000-seed weight (3.62 g and 3.29g) were also found from 4 seed stalks/plant, which was followed by 6 seed stalks/plant but minimum values were documented in no seed stalk pruning. In case of seed yield, maximum seed yield (643.66 kg/ha and $670.2 \mathrm{~kg} / \mathrm{ha}$ ) was produced in 6 seed stalks/plant. Morozowska et al. (2009) showed a significant influence on the bulb size, the number of seed stalks and the inflorescence diameter. Tall seed stalks easily fall down, which causes losses in seed yield (Rudolph, 1988).

Table 1 Seed yield and yield attributes of summer onion as affected by number of stalks at FSRD site Kadamshahar, Rajshahi during the year of 2009-10 and 2010-11.

\begin{tabular}{l|c|c|c|c|c|c|c|c|c|c}
\hline \multirow{2}{*}{$\begin{array}{c}\text { No. of } \\
\text { stalk }\end{array}$} & $\begin{array}{c}\text { Seeded fruits/ } \\
\text { umbel }\end{array}$ & \multicolumn{2}{c|}{$\begin{array}{c}\text { Seed wt/ } \\
\text { umbel }(\mathrm{g})\end{array}$} & \multicolumn{2}{c|}{$\begin{array}{c}\text { No. of seeds/ } \\
\text { umbel }\end{array}$} & $\begin{array}{c}1000-\text {-seed wt } \\
(\mathrm{g})\end{array}$ & \multicolumn{2}{c}{$\begin{array}{c}\text { Seed yield } \\
(\mathrm{kg} / \mathrm{ha})\end{array}$} \\
\cline { 2 - 11 } & $\begin{array}{c}2009- \\
10\end{array}$ & $\begin{array}{c}2010- \\
11\end{array}$ & $\begin{array}{c}2009- \\
10\end{array}$ & $\begin{array}{c}2010- \\
11\end{array}$ & $\begin{array}{c}2009- \\
10\end{array}$ & $\begin{array}{c}2010- \\
11\end{array}$ & $\begin{array}{c}2009- \\
10\end{array}$ & $\begin{array}{c}2010- \\
11\end{array}$ & $\begin{array}{c}2009- \\
10\end{array}$ & $\begin{array}{c}2010- \\
11\end{array}$ \\
\hline 4 & $303.24 \mathrm{a}$ & $254.4 \mathrm{~b}$ & $3.95 \mathrm{a}$ & $3.31 \mathrm{~b}$ & $690.11 \mathrm{a}$ & $703.7 \mathrm{a}$ & $3.62 \mathrm{a}$ & $3.29 \mathrm{a}$ & $571 \mathrm{~b}$ & $626 \mathrm{~b}$ \\
6 & $293.65 \mathrm{~b}$ & $297.0 \mathrm{a}$ & $3.76 \mathrm{a}$ & $3.85 \mathrm{a}$ & $670.11 \mathrm{~b}$ & $700.6 \mathrm{a}$ & $3.61 \mathrm{a}$ & $3.17 \mathrm{a}$ & $644 \mathrm{a}$ & $670 \mathrm{a}$ \\
$\begin{array}{l}\text { No } \\
\text { pruning }\end{array}$ & $277.43 \mathrm{c}$ & $242.0 \mathrm{~b}$ & $3.3 \mathrm{~b}$ & $3.92 \mathrm{a}$ & $621.77 \mathrm{c}$ & $613.5 \mathrm{~b}$ & $2.95 \mathrm{~b}$ & $2.88 \mathrm{~b}$ & $599 \mathrm{ab}$ & $561 \mathrm{c}$ \\
\hline $\mathrm{CV}(\%)$ & 2.90 & 10.68 & 10.01 & 9.02 & 1.82 & 5.47 & 4.80 & 7.01 & 9.75 & 4.55 \\
\hline
\end{tabular}

\section{Effects of boron levels}

Significant variation was observed in seed yield and yield attributes of onion among three boron levels (Table 2). In 2009-2010, the maximum number of seeded fruits/umbel (307) and seed weight/umbel (3.94 g) were observed from 2 $\mathrm{kg} \mathrm{B} / \mathrm{ha}$. The maximum number of seeds/umbel (679) and 1000-seed weight ( $3.70 \mathrm{~g}$ ) were also found from $2 \mathrm{~kg} \mathrm{~B} / \mathrm{ha}$ followed by $1 \mathrm{~kg} \mathrm{~B} / \mathrm{ha}$ treatment. In 2010-2011, maximum number of seeded fruits/umbel (283.2) and seed weight/umbel $(4.17 \mathrm{~g})$ were found from $1 \mathrm{~kg}$ boron/ha. Significantly higher number of seeds/umbel (688.3) and 1000-seed weight (3.58 g) were also found from $1 \mathrm{~kg}$ boron/ha followed by $2 \mathrm{~kg}$ boron/ha treatment. But in both the years, minimum was found in control plot. In case of seed yield, the maximum seed yield (640.22 kg/ha and 655.9) was produced from $2 \mathrm{~kg} \mathrm{~B} /$ ha treated plot, which was followed by $1 \mathrm{~kg} \mathrm{~B} / \mathrm{ha}$ treated plot but minimum in control plot. Phosphorus, 
potassium, and boron application had a positive effect on the productivity of onion (Howlader et al., 2012). According to Robinowitc et al. (2002) showed that foliar sprays of boron improved onion yields of the two consecutive seasons.

Table 2. Seed yield and yield attributes of summer onion as affected by different levels of boron at FSRD site, Kadamshahar, Rajshahi during the year of 2009-10 and 2010-11.

\begin{tabular}{|c|c|c|c|c|c|c|c|c|c|c|}
\hline \multirow{2}{*}{$\begin{array}{l}\text { Boron } \\
\text { levels } \\
\text { (kg/ha) }\end{array}$} & \multicolumn{2}{|c|}{$\begin{array}{c}\text { Seeded } \\
\text { fruits/umbel }\end{array}$} & \multicolumn{2}{|c|}{$\begin{array}{l}\text { Seed wt/ } \\
\text { umbel g) }\end{array}$} & \multicolumn{2}{|c|}{$\begin{array}{c}\text { No. of seeds/ } \\
\text { umbel }\end{array}$} & \multicolumn{2}{|c|}{$\begin{array}{c}\text { 1000-seed wt } \\
\text { (g) }\end{array}$} & \multicolumn{2}{|c|}{$\begin{array}{l}\text { Seed yield } \\
\text { (kg/ha) }\end{array}$} \\
\hline & $\begin{array}{c}2009- \\
10\end{array}$ & $\begin{array}{c}2010- \\
11\end{array}$ & $\begin{array}{c}2009- \\
10\end{array}$ & \begin{tabular}{|c|}
$2010-$ \\
11
\end{tabular} & $\begin{array}{c}2009- \\
10\end{array}$ & $\begin{array}{c}2010- \\
11\end{array}$ & $\begin{array}{c}2009- \\
10\end{array}$ & \begin{tabular}{|c|}
$2010-$ \\
11
\end{tabular} & $\begin{array}{c}2009- \\
10\end{array}$ & $\begin{array}{c}2010- \\
11\end{array}$ \\
\hline 0 & 277.55 & 261.3ab & $3.16 \mathrm{~b}$ & $3.06 \mathrm{~b}$ & 638.33 & 6451 & $3.007 b$ & $2.65 c$ & 562ab & $553.6 \mathrm{~b}$ \\
\hline 1 & $289.62 b$ & $283.2 \mathrm{a}$ & 3.90a & $4.17 \mathrm{a}$ & $664.00 \mathrm{~b}$ & 688.3a & 3.58ab & 3.58a & $612 \mathrm{ab}$ & $647.6 \mathrm{a}$ \\
\hline 2 & $307.20 \mathrm{a}$ & $248.4 \mathrm{~b}$ & 3.94a & 3.85a & $679.67 a$ & $684.5 \mathrm{a}$ & 3.70a & $3.41 \mathrm{ab}$ & 640a & 655.9a \\
\hline CV (\%) & 2.90 & 10.68 & 10.01 & 9.02 & 1.82 & 5.4 & 4.8 & 7.01 & 9.75 & 4.55 \\
\hline
\end{tabular}

Table 3. Seed yield and yield attributes of summer onion as affected by different numbers of stalk and boron levels at FSRD site, Kadamshahar, Rajshahi during the year of 2009-10 and 2010-11.

\begin{tabular}{|c|c|c|c|c|c|c|c|c|c|c|c|}
\hline \multicolumn{2}{|c|}{$\begin{array}{c}\text { Boron } \times \\
\text { Stalk }\end{array}$} & \multicolumn{2}{|c|}{$\begin{array}{c}\text { Seeded } \\
\text { fruits/umbel }\end{array}$} & \multicolumn{2}{|c|}{$\begin{array}{c}\text { Seed wt/umbel } \\
\text { (g) }\end{array}$} & \multicolumn{2}{|c|}{$\begin{array}{l}\text { No. of seeds/ } \\
\text { umbel }\end{array}$} & \multirow{2}{*}{\multicolumn{2}{|c|}{$\begin{array}{c}\begin{array}{c}\text { 1000-Seed wt } \\
(\mathrm{g})\end{array} \\
3.08 \mathrm{~b} 2.80 \mathrm{def}\end{array}$}} & \multicolumn{2}{|c|}{$\begin{array}{l}\text { Seed yield } \\
\text { (kg/ha) }\end{array}$} \\
\hline \multirow{3}{*}{$\mathrm{S}_{1}$} & $\mathrm{~B}_{0}$ & $287.20 \mathrm{~cd}$ & 277.3abc & $2.78 \mathrm{c}$ & $2.81 \mathrm{f}$ & 669.33b & 672.3abc & & & 495.33c & $533.4 d$ \\
\hline & $\mathrm{B}_{1}$ & 317.61a & 238.6cd & 3.48ab & 3.57cde & 688.66b & 720.2ab & $3.91 \mathrm{a}$ & 4.03a & 585.66ab & $645.1 b$ \\
\hline & $\mathrm{B}_{2}$ & 299.88bc & 247.4bcd & 3.62ab & 3.55cde & 712.33a & & $3.88 a$ & $3.05 \mathrm{~cd}$ & $654.00 a$ & 698.2a \\
\hline \multirow{3}{*}{$\mathrm{S}_{2}$} & $\mathrm{~B}_{0}$ & 283.67d & 296.8b & & & $644.66 c$ & & $3.15 b$ & & $503.00 \mathrm{~b}$ & 596.3c \\
\hline & $\mathrm{B}_{1}$ & 312.77ab & 312.8a & $4.06 a$ & $4.55 a$ & 695.66ab & 707.3ab & 3.69a & $3.54 b$ & $669.17 \mathrm{a}$ & 712.9a \\
\hline & $\mathrm{B}_{2}$ & 289.68cd & 281.2abc & $4.12 \mathrm{a}$ & 3.86bcd & 698.00ab & 737.4a & 3.99a & $3.29 \mathrm{bc}$ & $649.00 \mathrm{a}$ & 701.5a \\
\hline \multirow{3}{*}{$\mathrm{S}_{3}$} & $\mathrm{~B}_{0}$ & 261.77e & 209.9d & 3.62ab & 3.25def & $601.00 \mathrm{~d}$ & $597.4 d$ & $2.79 c$ & $2.47 f$ & 496.36c & 531.1d \\
\hline & $\mathrm{B}_{1}$ & $291.22 \mathrm{~cd}$ & 298.3ab & $4.11 \mathrm{a}$ & 4.39ab & 627.66c & $637.4 \mathrm{~cd}$ & $3.14 b$ & 3.18bcd & $564.00 \mathrm{~b}$ & 584.8c \\
\hline & $\mathrm{B}_{2}$ & $289.28 d$ & 217.8d & $4.14 \mathrm{a}$ & 4.13abc & $636.66 \mathrm{c}$ & 605.8cd & $3.23 b$ & 3.99cde & $562.00 \mathrm{~b}$ & 567.9cd \\
\hline \multicolumn{2}{|c|}{ CV (\%) } & 2.90 & 10.68 & 10.01 & 9.02 & 1.82 & 5.47 & 4.80 & 7.01 & 9.75 & 4.55 \\
\hline
\end{tabular}

$S_{1}=4, S_{2}=6, S_{3}=$ No pruning, $B_{0}=0, B_{1}=1, B_{2}=2 \mathrm{~kg} / \mathrm{ha}$

\section{Interaction effects of seed stalk and boron levels}

Interaction effect of seed stalk and boron levels had significant effect on seed yield and yield attributes of onion (Table 3). In 2009-2010, the maximum number of seeded fruits/umbel (317) and 1000-seed weight (3.91 g) were found from 4 stalks/plant fertilized with $1 \mathrm{~kg}$ B/ha which were statistically similar with 6 
stalks/plant fertilized with same dose. Higher number of seeds/umbel (712) was found from 4 stalks/plant with $2 \mathrm{~kg} \mathrm{B/ha,} \mathrm{which} \mathrm{was} \mathrm{identical} \mathrm{to} 6$ stalks/plant fertilized with $1 \mathrm{~kg} \mathrm{B/ha}$ but the minimum (601) in control plot. In 2010-2011, significantly maximum number of seeded fruits/umbel (297.0) was found from keeping 6 stalks/plant, and maximum seed weight/umbel (3.85 g) was observed from keeping 6 stalks/plant which was statistically similar to no pruning treatment. Both the years, maximum seed yield $(712.9 \mathrm{~kg} / \mathrm{ha}$ and $669.17 \mathrm{~kg} / \mathrm{ha})$ was produced from 6 stalks/plant fertilized with $1 \mathrm{~kg}$ boron/ha which, was statistically identical to 4 stalks/plant fertilized with $2 \mathrm{~kg}$ boron/ha and 6 stalks/plant with same dose of boron. This might be due to higher number of seeds/umbel and 1000-seed weight produced from 4 and 6 stalks/plant fertilized with 1 and $2 \mathrm{~kg}$ boron/ha. But the minimum seed yield (495.33 and $533.40 \mathrm{~kg} / \mathrm{ha}$ ) was found from 4 stalks/plant fertilized with boron control plot. These results are in agreement with the results of Mehrotra et al. (1977) who reported that boron influences seed yield of oil seed and spices crops.

\section{Conclusion}

From two years' observation, it is revealed that seed stalk and boron both either in single or in combination had significant effect on yield of onion seeds. The maximum seed yield of summer onion was produced keeping 6 stalks/plant fertilized with $1 \mathrm{~kg}$ boron/ha which was statistically identical to 6 stalks/plant fertilized with $2 \mathrm{~kg}$ boron/ha and keeping 4 stalks/plant with $2 \mathrm{~kg}$ boron/ha in the High Barind Tract (AEZ 26).

\section{Refeences}

BBS. 2008. Bangladesh Bureau of Statistics, Statistics Division, Ministry of Planning. Government of the People's Republic of Bangladesh, Dhaka, Bangladesh. P.136.

Brewster, J. L. 1994. Onions and other vegetable Alliums. CAB International, UK. 236P.

FAO. 1998. FAO Yearbook, Food and Agriculture Organization of United Nations, Rome, Italy. 51: 135-136.

Gomez, K. A. and A. A. Gomez. 1984. Statistical Procedures for Agricultural Research. $2^{\text {nd }}$ edn., John Wiley and Sons. New York.

Howlader, M. M., M. N. Yousuf, M. M. Kamal, M. R. Khatun and H. M. K. Bashar. 2012. Effect of phosphorus, potassium and boron on onion seed production. Int. J. Sustain. Agril. Tech. 8(7):28-30.

Hrdp.1995. Training Manual, Winter Vegetable and Spices Production. Horticulture Research and Development Project (FAO/UNDP/ASDP Project: BGD/87/2005) and BADC, Dhaka. 285P.

Krishi Dairy. 2007. Krishi Dairy, Agriculture Information Service, Ministry of Agriculture, Govt. of the People's Republic of Bangladesh, Dhaka. 
Mehrotra, O. N., R. D. L. Srivastara and P.H. Misra. 1977. Effect of micronutrient on the growth, yield and quality of Indian mustard. Indian J. Agric. Chem. 10: 81-86.

Morozowska Maria I., Roman Hołubowicz. 2009. Effect of bulb size on selected morphological characteristics of seed stalks, seed yield and quality of onion (Allium cepa L.) seeds. Folia HorticultureAnn. 21/1: 27-38.

Rahim, M. A., M. M. U. Amin and M. A. Haider. 1993. Onion seed production tecnology in Bangladesh. Allium Improvement Newsletter 3: 33.

Robinowitc Haim D. h, Lesley currah. 2002. Allium Crop Science: Recent advances. CABI International, UK. 218P.

Rudolph, M. 1988. Beeinflussung der Standfestigkeit und andere Merkmale bei.

Shaikh, A. H. B. S. Vyakaranahal, M. Shekhargouda and P. R. Dharmatii. 2002. Influence of bulb size and growth regulators on growth, seed yield and quality of onion cv. Nasik Red. Seed Res. 30: 223-229.

Thompson, J. R. 1979. An Introduction to Seed Technology. Leonard Hill Books Ltd. London. P. 19. 